\title{
Implementation of Islamic Education through Religious Character at SMK Darussalam Karangpucung Cilacap
}

\author{
Guntur Dwi Purwanto ${ }^{1}$, Fauzi ${ }^{2}$ \\ 1,2 Institut Agama Islam Negeri Purwokerto, Indonesia \\ 201771018@mhs.iainpurwokerto.ac.id,fauzi@iainpurwokerto.ac.id
}

\begin{abstract}
Islamic religious education is needed to shape the religious character of students into better people. This study aims to describe and explain the existence of Islamic education activities through religious characters. This research is included in a qualitative descriptive study because this study describes the process of forming the religious character of students through religious learning activities carried out at SMK Darussalam Karangpucung. The data analysis technique in this study includes several stages, namely a) data reduction, namely collecting and grouping data, b) presenting data, this activity describes and explains data, and c) concluding, in this activity, namely drawing conclusions after reducing and presenting data. The results of this study are finding several implementations of the formation of students 'religious character through several religious activities, including a) praying before and after learning, reading Asmaul Husna and Juz' Amma, b) Lecture 10 minutes, c) playing infaq, d) sunnah prayers, e) compulsory prayers (noon prayers), f) healthy Fridays, clean Fridays, Taqwa Fridays, and Literacy Fridays, and g) saying greetings when meeting residents of SMK Darussalam Karangpucung ( Teachers, friends, administration and so on).
\end{abstract}

Keywords

religious character; implementation of islamic education; SMK Darussalam

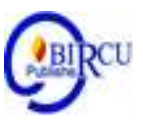

\section{Introduction}

The world of education is inseparable with the existence of a process of evaluation and accreditation that is often a benchmark of the quality of a formal or non-formal education institution. The process of evaluation or in English is often referred to as evaluation is a process of measurement and comparison of the results of work in fact achieved with the results that should be achieved. In order for the quality of education to be as expected by the community, measurement standards are needed. If the desired standard is national, then the standard should also be national as well. (Nasution et al, 2019)

Education in every school aims to form students who are intelligent and have noble character according to their respective beliefs. Besides that, the development of technology in the world of education makes us always think ahead following technological developments. Between education and schools are always related, each school has its characteristics so that it is known to be different from other schools. In addition, it is also to attract parents in considering their child's choice of school. Parents send their children to school in addition to aiming at studying but also aiming at learning / deepening their religion.

Today, there have been many modern schools that have followed the times, many industrial-based schools and Islamic boarding schools, this is to attract the interest of students, especially students who after graduating from school want to work directly. With such a goal, many students are looking for Vocational High Schools (SMK), in SMK many majors can be chosen depending on the interests of each person. 
One of the industrial-based Vocational High Schools (SMK) and Islamic boarding schools are SMK Darussalam Karangpucung Cilacap. Apart from introducing the industrial world, this school also aims to deepen the knowledge of Islam. This is for the provision of students in this 4.0 industrial revolution. Many challenges will be faced by students in the world of work. Students are expected to be able to keep up with the times in the industrial sector, without reducing religious values. However, along with the development of times and technology, many students ignore the sense of politeness towards older people. Several factors influence this, one of which is marked by excessive internet use without paying attention to what is good for him and what is not good for him.

One of the online media in Indonesia informed that there had been a brawl between students amid this Covid-19 pandemic. They not only threw stones at each other but also carried sharp weapons in the form of gear and sickles. It is not appropriate for students to carry these sharp weapons. This is very unfortunate for the police because it does not reflect someone who is educated. Coupled with students not paying attention to health protocols, this is very dangerous for the safety of students. To provide a deterrent effect, the police summoned the parents of the students and the school to solve the problem so that it does not happen again. This incident is one clear example of the deterioration of the character of students in Indonesia.

It takes a teacher figure to guide and teach students to be even better, especially in terms of character building. It aims to provide provisions when working and living in society. Hariandi (2016) in his research explained that education in schools must be organized systematically, to create competitive, moral, polite, ethical, and interactive students with social life, especially in the world of work.

In line with this, Prabowo et al (2020) added that in addition to having academic abilities, parents expect their children to have strong talents, skills, and character to make them a provision for navigating community life in the future. Therefore, parents also need to help teachers in shaping their students, especially in the family environment. Parents can exemplify their children in creating a peaceful, harmonious, and happy family through harmonious cooperation among all family members (Sutriyanti, 2016).

This is following the vision of SMK Darussalam Karangpucung Cilacap, namely a) to be a school that is waiting for morals, intellectually and politely in behavior; and b) professional in achieving achievements in competitions, cultural achievements, skill achievements, and achievements in competition in the achievement of looking for work. Not only the vision but here are several missions to make the vision a success. These include a) fostering a disciplinary and religious spirit in the school environment, and b) realizing the school literacy program and cultivating the character of students.

In addition to prioritizing knowledge, the character is also important to be instilled in every student. Every human being has a mind and mind that is tailored to his character. This is stated in the Qur'an Surah Shad verse 29 which means "The book that we sent to you is full of blessings so that they will meditate on its verses and think about learning a lesson".

Likewise, students in the SMK Darussalam Karangpucung Cilacap come from different backgrounds. An educator must have a way to invite and teach devotion to his students by looking at the background conditions of each student. Humans living in this world are given a mandate by Allah SWT to be khalifah fi al-ard (leaders on earth). The explanation is contained in the following words. 


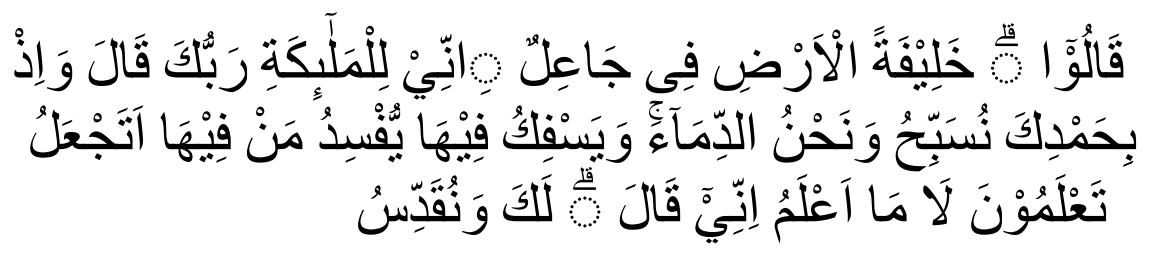

It means "Remember when your Lord said to the angels," I want to make the caliph on earth. "They said, "Are you going to make someone who corrupts and sheds blood there, while we praise You and purify Your name?" He said, "Truly, I know what you do not know".

Husaini (2011: 37) stated his opinion that school graduates or graduates who are produced are skilled in answering exam questions, have smart brains but are mentally and morally weak. The need for character building of students to become noble personalities, through various approaches that are tailored to the background of each school. With the existence of Islamic education in schools, students are expected to have Islamic values / religious character in every action they take. In addition, character education has recently been increasingly discussed as a solution to the decline in the quality of education in Indonesia (Kesuma, 2011: 3-4).

Hasbullah (2015) states that Islamic education is various forms of effort made by a person or group of people to change the standard of life to be better mentally, spiritually, and socially. The existence of Islamic education in schools is expected to shape the character of each student to become a good person. Rohman (2017) also expressed his opinion that in Islamic education there is a need for social interaction to build harmony with one another by emphasizing the existing social dimensions. The existence of Islamic education in schools is expected to have a significant impact in shaping the religious character of students. One of the aims of character education is to develop the abilities of students so that they can recognize, care for, internalize values so that they can behave as human beings (Samani \& Hariyanto, 2011: 46).

In accordance with the Law of the Republic of Indonesia number 20 of 2003 that,

"National education has the function of developing abilities and shaping dignified national character and civilization to educate the nation's life, aimed at developing the potential of students to become human beings who believe and have devotion to God Almighty, noble, healthy, knowledgeable, competent, creative, independent, and become a democratic and responsible citizen ".

Islamic education in schools is one of the supporters of the National Education System in increasing competent human resources in Indonesia. Annur (2018) argues that one alternative that can be done for character education in schools is by optimizing learning material for Islamic religious education. With the existence of Islamic religious education in schools, especially in vocational schools, it is hoped that it can increase the faith and piety of students in seeking knowledge, in balancing the advancement of knowledge in the industrial sector.

From an early age prospective students have been taught about religious character through education in Early Childhood Education (PAUD) / Kindergarten (TK), but no less important SMK as vocational education which aims to produce skilled people in the industry according to their fields respectively, are expected to have a religious character in accordance with the expectations of the nation. SMK Darussalam Karangpucung has five skill competencies, including a) Accounting \& Financial Institutions, b) Online Business \& Marketing, c) Light Vehicle Engineering \& Automotive, d) Computer \& Network Engineering, and e) Motorcycle Engineering \& Business. Based on observations made by 
researchers from March 27, 2021, to April 10, 2021, it is known that religious character education at SMK Darussalam Karangpucung is integrated with the learning process. In addition, religious character education is also carried out through the self-development of each student and industrial practice.

However, lately many incidents involving school children do not reflect that they are students, with a record of many negative things that students do both in the school environment and in the environment where they live. One of the real things that happen in the world of education is bullying. Bullying includes the act of controlling power to hurt someone verbally, physically, and psychologically so that the victim feels depressed, traumatized, and helpless (Sejiwa, 2008).

One of the bullying cases occurred in the city of Bandung Province, West Java, there were several cases of bullying that caused students to have their fingers amputated and even died. This incident is an extreme and fatal picture of physical and psychological bullying by students to their friends. This phenomenon of violence is a whip for all of us because students should not do something heartbreaking, let alone the loss of a person's life. This is because Islamic education in schools is considered less successful in making a positive contribution to students. Weak social control also affects the character building of students.

In addition, Muahimin (2010: 27) explains that several factors support the unsuccessfulness of Islamic religious education in schools, including a) the lack of being able to apply cognitive religious knowledge which makes the meanings and values that need to be internalized into students, b) lack of cooperation with general education programs, and c) lack of relevance to social changes taking place in society.

Still, following Muhaimin's (2013: 57-58) explanation, the dedication of Islamic Religious Education teachers has started to decline, teachers are more transactional at work, besides that parents pay less attention to children's religious education, shift orientation more towards materialism, and individualism and social control weak. An environment that does not pay attention to the principle of social piety usually will only form pious individuals in an exclusive box who are apathetic to the surrounding environment (Laisa, 2016).

It takes extra effort to shape the character of each student by the national personality and attention to the surrounding environment, both the school environment and the place of residence. The individual character will develop well, if it gets the right reinforcement, namely in the form of education (Maunah, 2015: 91).

Ainiyah (2013) states that character education is not the only material that is recorded and memorized but also as learning that is implemented in student activities through a process of habituation and exemplary both in the school environment and in the community environment. This is a form of teacher application in teaching religious character education to students, especially in the school environment.

Based on the explanation above, the formation of the religious character of students through Islamic education at SMK Darussalam Karangpucung is very necessary to form a good personality according to the teachings of Islam.

\section{Research Methods}

This research is qualitative, this type of research uses descriptive qualitative. Moleong (2014: 6) states that qualitative research is research that intends to understand the phenomena experienced by research subjects, such as behavior, motivation, etc. by describing them in the form of sentences. This study seeks to describe and explain the implementation of Islamic education in shaping the religious character of students at Darussalam Karangpucung Vocational High School. 
Sources of data in this study were students of class XI at SMK Darussalam Karangpucung on the Karangpucung-Majenang highway, Kilometer 02 number 08, Bojongsari, Ciporos, Kec. Karangpucung, Cilacap Regency, Central Java Province. SMK Darussalam Karangpucung was chosen in this study because it is one of the Vocational High Schools based on Islamic boarding schools and is in great demand by students.

The data analysis technique in this study uses a flow analysis model from Milles and Hubberman (2012), which includes, a) data reduction, this activity collects and classifies data, b) data presentation, this activity describes and explains the data, and c) draws conclusions, This activity draws conclusions after reducing and presenting data.

\section{III.Results and Discussion}

Following the results of interviews and direct observations at SMK Darussalam Karangpucung, the religious character that is implemented through Islamic education is as follows.

\subsection{Pray before and after learning, read Asmaul Husna and Juz 'Amma}

This activity is carried out before learning begins, students pray first, in addition to asking for blessings from Allah SWT, praying also aims to keep away from spirits who interfere with the learning process. After praying, continue reading Asmaul Husna and Juz 'Amma by reading short letters related to the theme/learning material. This activity aims to train and increase the reading acquisition of students' short letters. With routine habituation like this, students are expected to form religious characters. In addition, it can also increase merit. So the subject matter can be, the reward can also be.

\subsection{0-minute lecture}

This activity assigns students to conduct a lecture before the lesson begins. The theme to be carried must be following the learning material. This is done to train the courage of students. This habit is done routinely every day, so one day one student advances to lecture in front of the class. Even though it was only 10 minutes, students were very enthusiastic about doing the lecture. In addition to introducing themselves, this activity also trains students to speak in front of a crowd.

\subsection{Infaq playback}

Infaq playback is carried out after a 10-minute lecture activity. This activity is taught by the teacher to train students to do good deeds and share with others. For the nominal it does not matter, the important thing is that students are trained to share and be sincere when giving something to others. Besides that, it also trains students to always feel grateful when they get a fortune or something. This habit is expected to form the religious character of students. With the infaq screening, it is hoped that students will be closer to making friends.

\subsection{Sunnah Prayers}

Sunnah prayers at SMK Darussalam Karangpucung are held before the first break, at around 09.00 WIB. In the Covid-19 pandemic season, the teacher's enthusiasm to teach the dhuha prayer to students by keeping their distance and wearing masks did not diminish. To anticipate the accumulation of students, this activity is carried out alternately per class with a time limit of 10 minutes. This routine habit is expected to form the religious character of students by teaching the discipline of worship. Students are expected to be accustomed to doing this dhuha prayer not only at school but at home also doing dhuha prayer. 
Many benefits can be obtained from dhuha prayer, including being able to facilitate one's fortune, being able to ask Allah SWT, teaching discipline, and practicing responsibility for each student.

\subsection{Obligatory Prayer (Zuhur prayer)}

Before the break, the two students are trained to pray in the congregation, this is aimed at training the habits of students in the congregation of compulsory prayer. Not only at school, but this habit is also expected to be practiced at home. In addition to training students' awareness of the importance of congregational prayers, this activity also trains students to be on time in carrying out compulsory prayers. These zuhur prayers are carried out alternately so as not to cause a crowd. The habituation of this activity can form the religious character of students. This activity is also assisted and monitored by teachers so that students remain disciplined and diligent in carrying out their obligations as Muslims.

\subsection{Healthy Friday, Clean Friday, Taqwa Friday, and Literacy Friday}

Healthy Fridays were filled at SMK Darussalam Karangpucung with joint exercises involving all elements of the school community consisting of teachers and participants. These healthy Friday activities are carried out without compromising health protocols. With the existence of a healthy Friday, it is hoped that teachers and students will always be healthy and keep away from the Covid-19 virus that is hitting Indonesia. Healthy Friday activities are carried out on the first Friday.

This clean Friday is carried out on Friday the second week. This activity involves all elements in SMK Darussalam, namely teachers, students, administrative staff, and other school members. All elements clean the school area so that it is more comfortable for the learning process. Not only in the classroom but clean Friday is also done in the school area. Students are trained to maintain the school environment because cleanliness is part of faith. On the clean Friday here the teacher not only gives orders but also immediately cleans the school area. It aims to train the sensitivity of students. This habituation activity is expected to form the religious character of students, especially to maintain the cleanliness of the school environment.

Friday taqwa at SMK Darussalam is held on Friday the third week. This activity is carried out at the school mosque. This Friday taqwa activity begins with the recitation of the Yasin Quran for the teacher and all students. After that, it is continued with the recitation of dzikir and sholawat which ends with prayer together. This Friday taqwa is expected to build awareness between teachers and students and to instill an Islamic culture through the habituation of reading the Al-Quran, dzikir, and praying. With this positive activity, it is hoped that it can form the religious character of students to build awareness of the importance of reading the Al-Quran, dzikir, and praying. It doesn't stop at school, but this activity also trains students to do it at home. This Friday taqwa activity also trains students' obedience to Allah Swt in worship.

Literacy Friday at SMK Darussalam Karangpucung is conducted on Friday the fourth week. This activity is also carried out in the mosque using the "Islamic studies" method. The teacher conducts lectures aimed at students, in addition to sharing knowledge about religion, the teacher also motivates students to help each other with other friends, respect each other, maintain cohesiveness, and explain the dangers and effects of bullying. The lecturer also motivates students to always respect and respect teachers and the elements in the school environment. With the literacy Friday activity, it is hoped that it can form the religious character of students, especially to train inner sincerity. All of these activities are carried out alternately to practice positive routine habituation. 


\subsection{Saying greetings when meeting residents of SMK Darussalam Karangpucung}

(Teachers, friends, Administration, and so on)

This habit is done when the teacher meets students, students meet other students, employees/administration meets students. This activity involves all elements in SMK Darussalam Karangpucung to practice the habit of saying greetings. Besides that, it also aims to eliminate the arrogance that exists in everyone, with this activity all elements in school can get to know each other. This activity is expected to form the religious character of students to respect each other and reduce the arrogance that exists in every element of the school environment. With this program, the members of the same school and the school members are not arrogant.

\section{Conclusion}

Based on the results and discussion described above, it can be concluded that the implementation of Islamic education through the religious character of students at SMK Darussalam Karangpucung is carried out with several activities, these activities include, a) praying before and after learning, reading Asmaul Husna and Juz 'Amma, b) 10-minute lecture, c) infaq screening, d) sunnah prayer, e) obligatory prayer (noon prayer), f) healthy Friday, clean Friday, Taqwa Friday, and Friday 'at Literacy, and g) saying greetings when meeting residents of SMK Darussalam Karangpucung (teachers, friends, administrators, and so on).

\section{References}

Ainiyah, Nur. (2013). Pembentukan Karakter Melalui Pendidikan Agama Islam. Jurnal AlUlum. Vol, 13. No, 1.

Annur, Kurnianto Rido \& Rohmadi. (2018). Penerapan Karakter Religius pada Peserta Didik di MT's Muhammadiyah 3 Yanggong Ponorogo. Jurnal TARBAWI. Vol, 2. No,2.

Hariandi, Ahmad \& Irawan Yanda. (2016). Peran Guru dalam Penanaman Nilai Karakter Religius di Lingkungan Sekolah pada Siswa Sekolah Dasar. Jurnal Gentala Pendidikan Dasar. Vol, 1. No, 1.

Hasbullah, H M. (2015). Kebijakan Pendidikan Islam dalam Perspektif Teori. Jakarta: Raja Grafindo Persada.

Husaini, Adian. (2011). Pendidikan Islam Membentuk Manusia Berkarakter dan Beradab. Depok: Komunitas NuuN.

Kesuma, Dharma et al. (2011). Pendidikan Karakter Kajian Teori dan Praktik di Sekolah. Bandung: PT. Remaja Rosdakarya.

Laisa, Emna. (2016). Optimalisasi Pendidikan Agama Islam di Sekolah Melalui Pengembangan Budaya Religius (Studi pada SMK Darul Ulum Bungbungan Bluto Sumenep). Jurnal Islamuna. Vol, 3. No, 1.

Maunah, B. (2015). Pelaksanaan Pendidikan Karakter dalam Pembentukan Holistik Siswa. Jurnal Pendidikan Karakter. Vol, 5. No, 1.

Miles, MB dan Hubberman, A. M. (2012). Analisis Data Kualitatif. Jakarta: UI Press

Moleong, Lexy J. (2014). Metodologi Penelitian Kualitatif. Bandung: PT. Remaja Rosdakarya

Muhaimin. (2010). Pengembangan Kurikulum Pendidikan Agama Islam di Sekolah, Madrasah, dan Perguruan Tinggi. Jakarta: Rajawali Pers. 
Nasution, r. et al. (2019). Implementation of PAUD Unit Accreditation in South Padangsidimpuan City. Budapest International Research and Critics in Linguistics and Education (BirLE) Journal. P. 981-987

Prabowo, Sultan Hadi. Fakhruddin, Agus \& Rohman, Miftahur. (2020). Peran Orang Tua dalam Pembentukan Karakter Anak di Masa Pandemi Cofid-19 Perspektif Pendidikan Islam. Al-Tadzkiyyah: Jurnal Pendidikan Islam. Vol, 11. No, 2.

Rohman, Miftahur dan Mukhibat. (2017).Internalisasi Nilai-Nilai Sosio-Kultural Berbasis Etno-Religi di MAN Yogyakarta III. Edukasia: Jurnal Penelitian Pendidikan Islam . Vol, 12. No, 1.

Sejiwa. (2008). Bullying: Mengatasi Kekerasan di Sekolah dan Lingkungan Sekitar Anak. Jakarta: PT Grasindo.

Sutriyanti, Ni Komang. (2016). Peningkatan Mutu Pendidikan Karakter Melalui Peran Orang Tua dalam Keluarga. Jurnal Penjaminan Mutu.Vol, 2. No, 1.

Wahyudi, Muhammad. (2020). Impelementasi Pembelajaran Pendidikan Agama Islam (PAI) dalam Pembentukan Karakter Religius dan Sikap Kepedulian Sosial Siswa di SMK Negeri 1 Kota Batu. Jurnal Lughoti: Jurnal Pendidikan Bahasa Arab. Vol, 2. No, 1.

https://regional.kompas.com/read/2020/03/28/12252161/sederet-kasus-tawuran-antar-pelajardi-tengah-pandemi-corona?page=all diakses pada tanggal 17 April 2021.

https://www.kpai.go.id/publikasi/sejumlah-kasus-bullying-sudah-warnai-catatan-masalahanak-di-awal-2020-begini-kata-komisioner-kpai diakses pada tanggal 18 April 2021. 